\title{
Preface
}

\section{Ways of knowing}

\author{
Mike Cooley
}

Published online: 27 October 2013

(C) Springer-Verlag London 2013

The prose poem, A GRAND TOUR, is based entirely on Mike's knowledge and recollection of the craft skills encountered in "A Grand Tour" of this small town of Tuam in County Galway. All the places described and the craftspeople mentioned are real. Many of their families continue to practice the skills described.

Mike embarked on a career in engineering design, primarily in the aerospace industry. He was increasingly concerned about the misuses of science and technology and sought with others to propose constructive alternatives which would celebrate human skills and be environmentally desirable. In particular, he was concerned that human beings were gradually being reduced to machine appendages and deeply regretted the fact that this was occurring at a time when there were constructive alternatives worthy of attention such as human-centred systems.

The prose poem, INSULTING MACHINES, reflects these concerns and urges us to re-examine our social responsibility, whilst options are still open to us.

Mike Cooley, author of the seminal book, Architect or Bee?, has a wide range of interests. From an early age, he was fascinated by the skills displayed by craftspeople and used to spend hours after school and during school holidays visiting the various workshops in the town and chatting with the craftspeople about different materials and techniques. He was convinced that these skills and talents were an important inheritance for future generations, and this motivated much of his subsequent research.

M. Cooley $(\bowtie)$

Chairman, AI \& Society Board, 95 Sussex Place,

Slough SL1 1NN, UK

e-mail: m.cooley@btconnect.com

\section{A GRAND TOUR}

1.1 Images of Craft Skills in 1940s Tuam, by Mike Cooley

It was a place of unselfconscious artists/craftspeople whose embodied knowledge is that marvel, human skill

which causes inert tools to spring into life as biddable extensions of the knowing hand, producing art concealed as work which always revealed the hand of the maker.

Where tools and materials supported those, skilled with talents fine-tuned over centuries

and whose tacit knowledge and sense of quality lurked in unpretentious work spaces.

Artefacts hidden in the guise of the ordinary so familiar as to be unnoticed

For we see but little of what is there and find instead, merely what we seek.

This then was the setting for a grand tour in a small place,

guided only by the tutor of his intrusive curiosity in this, his Florence on the Nanny,

a treasure trove of much used but little appreciated artefacts.

Now on a drizzly October day he would embark upon his initial Wanderjahre

by going nowhere special -for the greatest journeys are always in the mind.

Perched halfway down the Tullinadaly hill, stood the workshop of Henry Creighton \& Son -coach builders. 
The huge sliding front doors, like the curtains in a theatre,

slid back to reveal the cavernous workshop behind.

A hand-made side car nearing completion, where father coached son as his father had done. Then armed only with a spokeshave, blocks of wood were transformed

into delicate, graceful wheel spokes like the limbs of a ballet dancer.

At the back, their very own ring of fire where the heat expanded the wheel rim

so that it fitted snugly and tightened the wheel as it contracted.

Fitted to a well greased axle, soon to take the Lynskey family into town on Sundays

If Jarlath's chariot had a Creighton wheel, where might Tuam be today?

A stone's roll downhill, almost unnoticed-

hid the tiny snug leather-scented workshop of shoemaker Doris Hosty.

The shoe-last in the window, a symbol and a tool with paraffin lamp of eye damaging inadequacy

where handmade shoes seemed to grow from the materials spread on a small work surface

while throughout the town there was no shortage of those to testify

that the shoes she made would fit like a glove, put a spring in your step and last for years.

One proud owner known for hyperbola, asserted that any self respecting corpse

would be proud to be laid out in them.

Now, meandering along the Old gardens pathway to the Old Road where the Rooney brothers

sculpted beneath the galvanised roof of their windswept workspace.

There they 'liberated' Angels or Celtic Crosses as if by magic

from the pregnant stone in which they could already see the figure

and would remove 'all that was not David' until he emerged resplendent.

Then the hand eye and brain combined to direct the spectacular chisel movements

And beneath its cutting edge, beauty was manifest.

Yet these artist craftspeople were kept 'below the salt' by the inadequate name: stonecutter.

Then a further ten minutes to The Mall, just past the cinema where the anvil bells

of the glowing forge rang out and Joe Connolly coaxed crude metal into intricate shapes as if it were the plasticine of his hand and brain co-ordination.

This was design by doing, as customers imagined aloud what they desired in practice

by discussing the number of twirls and leaves they would like to grace their gates. There the intricate balance between imagination and reality was forged. Joe's work adorned and secured many an entrance and exit

even the convent had its boundaries set by him.

Then on to the Ballygaddy Road, a place of many talents

and where the dressmaker Mrs Flaherty toiled in her house-cum-workshop.

Armed to the teeth with pins in her lips in readiness for fixing

she employed skills that defined the bespoke and were evident in each measurement and scissor cut.

A huge iron, retrieved from the open fire, hissed trainlike as it folded

and flattened the willing material on a room-dwarfing table.

Her level playing field in an unfair world.

There, flat materials would be formed to caress that extraordinary variety

of three dimensional contours that is the human body. Whether for a two piece suit, a wedding dress or a ballgown, her fine feathers made fine birds.

What home in MacHale Terrace did not boast at least one garment fashioned by Mrs Flaherty?

She could metamorphise a mother's wedding dress into a confirmation gown for her daughter then a first communion dress for her youngest.

But a few paces away, stood the workshop of the O'Rourke carpenters

where doors were custom made of well discussed, highly figured and seasoned wood.

Each would fit snugly into an existing frame however skewed-

a one-off fitted to perfection in an irregular world, not some tolerated item imposing itself.

This respected artefact would be visited three months later to ensure that it had settled in

with careful final adjustment to make it gently clonk close on the inner and outer worlds

-a threshold of tension between the public and private domains.

And just visible tall upright threatening, lurking in the workshop corner, two coffins

Handcrafted reminders of our mortality. 
Where to stop in this Hermitage of treasures? Perhaps at Paddy Donoghue's,

whose hand stitched, brass embellished harnesses set off many a fine horse,

or famed footballer Frank son of Jim Stockwell whose shop signs with letters

defiantly stood proud of their flat surface;

Why not the bakers Clorans and Lydons where ovens were fired up at around 4.am

or Bob Holmes barber and provider of apprenticeships?

Not forgetting the Walsh brothers -a quartet of tailoring talents

three in Tuam and Richard in Kilcreevanty

or the Holian family of plasterers, bricklayers and builders.

Or Tommy Acton the bonesetter 'with the gift' in Desmesne cottages.

And precious to me are the cherished youthful memories of dad's workshop

where I learned to anneal copper and temper steel and that mecca of skills orchestrated by Franz Kaplan in the workshop of the sugar factory

or..... an ever growing repertoire limited only by our own lack of insight.

\section{INSULTING MACHINES}

\subsection{By Mike Cooley}

It is a graceful degradation, bristling with paths not taken

Supercharged by Taylor's one best way

with all the zeal of the monotheist

Where Schumpeter shoves, Kondratiev waves and Gladwell points

All in hot pursuit of singularity.

Behold the strange phyla as they stalk their makers They too can walk, feed, talk and -some say- think.

We create devices and then they create us.

Narcissus-like, we gaze into a pool of technology and see ourselves.

We acquiesce in our own demise, setting out as participants

and metamorphosing into victims.
The diagnosis is serious: a rapidly spreading species' loss of nerve

Tacit knowledge is demeaned whilst propositional knowledge is revered.

Who needs imagination when there are facts ?

A human enhancing symbiosis ignored whilst a dangerous convergence proceeds apace as human beings confer life on machines and in so doing diminish themselves.

Your calculus may be greater than his calculus but will it pass the Sullenberger Hudson river test ? Meantime, the virtual is confused with the real -as parents lavish attention on the virtual child whilst their real child dies of neglect and starvation.

Potential and reality are torn apart as change is confused with progress

with slender knowledge of deep subjects

-you proceed with present tense technology,

obliterating the past and with the future already mortgaged.

The court of history may find you intoxicated with species arrogance

recklessly proceeding without a Hippocratic Oath.

Meantime, the deskiller is deskilled, as a tsunami of technology rocks our

foundations. The multinational apologist solemnly declares

"We should have the courage to accept our true place in the evolutionary hierarchy

-namely animals, humans and post singularity systems".

Now the sky darkens with pigeons coming home to roost

and the mine canaries topple from their perches unnoticed.

That distant sound grows louder.

Is it the life affirming energy of Riverdance or the clacking hooves of the Four Horsemen ?

That music, is it 'Ode to Joy' or is it 'Twilight of the Gods?'

As the embrace tightens into genteel strangulation -will the seducer in final deception whisper "Shall I compare thee to a Summer's day ?" 